\title{
TINJAUAN TEOLOGIS TENTANG TAKUT AKAN TUHAN BERDASARKAN KITAB AMSAL DAN IMPLEMENTASINYA DALAM HIDUP KEKRISTENAN
}

\author{
Ril Tampasigi \\ sttjaffraymakassar@yahoo.co.id \\ Peniel CD. Maiaweng
}

\begin{abstract}
ABSTRAK
Ril Tampasigi, Tinjauan Teologis Tentang Takut Akan Tuhan Berdasarkan Kitab Amsal Dan Implementasinya Dalam Hidup Kekristenan.

Sebagai tujuan penelitian adalah Untuk memaparkan konsep Takut akan TUHAN berdasarkan kitab Amsal, Untuk menjelaskan manfaat dari Takutakan TUHAN. Dan Untuk menjelaskan implementasinya dalam kehidupan Kekristenan setiap hari.

Adapun metode yang digunakan dalam penelitian ini adalah metode kualitatif yaitu metode penelitian Kepustakaan (library research), terhadap berbagai sumber data antara lain: Alkitab, tafsiran-tafsiran kitab Amsal dan buku-buku yang membahas tentang Takut akan TUHAN serta penulis menggunakan metode eksegesis. Yang disusun secara deskriptif untuk mencapai sasaran dan tujuan penulisan.

Dalam penelitian ini, ditemukan hasil bahwa Kekristenan seharusnya hidup berdasarkan takut akan TUHAN dengan menyadari akan kemahakuasaan-Nya, kekudusan-Nya, kemahahadiran-Nya dan kemahatahuanNya dalam setiap aspek kehidupan manusia lewat tindakan dan perilaku manusia. Banyak hal dalam dunia ini yang akan membuat manusia merasa takut dan gentar, baik itu ketakutan terhadap sesamanya manusia maupun ketakutan terhadap hal-hal yang lainnya. Takutakan TUHAN merupakan suatu perasaan takut yang positif bukan negatif. Takutakan TUHAN bukan seperti perasaan takut yang dialami oleh manusia terhadap hal-hal yang biasa, tetapi takutakan TUHAN merupakan penghormatan manusia terhadap TUHAN.
\end{abstract}

Kata Kunci: Takut akan Tuhan, Kitab Amsal, dan Hidup Kekristenan. 


\section{PENDAHULUAN}

\section{Latar Belakang Masalah}

Kemajemukan agama merupakanfenomena yang ada sejak adanya kehidupan manusia di bumi, yaitu sejak lahirnya kesadaran diri manusia mengenai keterbatasan dirinya dan kesadaran mengenai kelebihan sesuatu yang ada di luar dirinya sendiri. Inilah yang disebut Calvin sebagai semen Religius, dimana tidak seorangpun di dunia ini yang tidak memiliki kesadaran akan adanya keberadaan yang lebihtinggi yang olehnya ia berasal dan yang kepada-Nya ia menyembah. ${ }^{1}$

Bangsa Indonesia merupakan bangsa yang beragama dan terdiri dari berbagai suku, bahasa, dan ras. Setiap agama memiliki kepercayaan yang berbeda-beda dan semua agama percaya kepada allahnya masingmasing, ada yang menyembah pohon, batu-batu dan kepercayaan lainnya. John Hick berkata, "setiap agama itu masing-masing punya allahnya. Sebagai oknum yang menjadi sumber pengharapan dan ketakutan". ${ }^{2}$ Lebih lanjut Hick berkata, "Allah itu adalah "The Eternal One" atau "The Real". Hikc, memakai istilah The Eternal One, di mana Dia adalah oknum yang tak terlukiskan dari tradisi-tradisi mistik, apakah itu Plotinus, Upanishads, dan pada sisi yang lain Dia adalah Allah yang kudus dari pengalaman teistik, misalnya Allah Israel, ataukah allah orang India".

Pada masa Perjanjian Lama bangsa Israel mengenal Allah dengan sebutan YHWH. Menurut tradisi bangsa Yahudi nama YHWH merupakan sebutan bagi suatu pribadi yang sangat mereka kagumi, hormati, dan junjung tinggi. Oleh sebab itu bagi bangsa Israel siapa pun dia tanpa terkecuali tidak diperbolehkan menyebut nama ini dengan sembarangan (Kel. 20:7). "Menurut PL, Allah Israel yang satudan kudus mengatasi dunia material dan tidak boleh digambarkan dalam bentuk

${ }^{\text {I}}$ Stevri I. Lumintang, Teologi Abu-Abu (Malang: Gandum Mas, 2004), 43.

${ }^{2}$ John Hick, Religious Pluralism dan Salvation (Faith \&Philosophy Journal Vol.5 1988), 371. Diaksestanggal 23 April 201l.Tersedia di http://www.google.co.id/ search?client=firefox-a\&rls=org.mozilla\%3AenUS\%3 Aofficial\&channel =s\&hl=id \& source $=$ hp \&\&q= pendapat + para + ahli + theologia + ttg + adanya + Allah\&meta $=\& b t n G=$ Penelusuran+Google.

${ }^{3}$ John Hick, Religious Pluralism dan Salvation (Faith \& Philosophy Journal Vol.5 1988), 37l. Diaksestanggal 23 April 201l.Tersediadi http://www.google.co.id/ search?client=firefox-a\&rls=org.mozilla\%3AenUS\%3Aofficial\&channel=s\& $\&$ l=

id\&source=hp\&q=pendapat + para + ahli + theologia + ttg + adanya + Allah\& $\&$ meta $=\& b \operatorname{btnG}=P e$ nelusuran+Google 
apapun" (Ul. 4:12, 15-24). ${ }^{4}$ Bangsa Israel menyembah Allah yang hidup dan tidak diizinkan untuk percaya dan menyembah allah manapun dan dalam bentuk apaun, selain dari pada Allah YHWH. Perintah yang terpenting yang diberikan oleh TUHAN Allah kepada bangsa Israel ketik abangsa ini keluar dari Mesir adalah takut akan TUHAN dalam segala tingkahlaku dan tindakan.

Ditengah-tengah kemajemukan agama sekarang ini, kekristenanpun selayaknya hidup sebagaimana bangsa Israel hidup pada zaman Perjanjian Lama. Kekristenan seharusnya tetap percaya akan adanya Allah yang esa dan tetap hidup dalam takut akan TUHAN. Kehidupan setiap orang Kristen harus mencerminkan sikap hormatnya terhadap TUHAN (dalam pergaulan, perkataan, maupun tindakan), namun ironisnya kehidupan yang setiap orang Kristen jalani saat ini tidak memperlihatkan sikap hormat terhadap Allah yang esa tersebut. Seharusnya, sebagai orang percaya yang hidupnya berada di tengahtengah bangsa yang memiliki kepercayaan yang berbeda-beda orangorang Kristen menyatakan penghormatannya terhadap Allah melalu isikap dan tindakannya setiap hari.

Kitab Amsal memberikan pengajaran, nasihat dan petunjukpetunjuk praktis tentang hidup yang berdasarkan takutakan TUHAN. Dalam kitab Amsal setiap orang diperingatkan untuk memiliki sikap yang takutakan TUHAN. Dalam segalahal apa pun yang manusia perbuat dan katakan harus berdasarkan takutakan TUHAN. Oleh sebab itu, penulis melihat kitab ini sebagai salah satu kitab dalam Perjanjian Lama yang tepat untuk dijadikan dasar bagi penulis dalam memberikan pengajaran yang benar tentang konsep takut akan TUHAN.

Melihatkondisi yang demikian, maka penulis tertarik untuk mengangkat judul ini: "TINJAUAN TEOLOGIS TENTANG TAKUT AKAN TUHAN BERDASARKAN KITAB AMSAL DAN IMPLEMENTASINYA DALAM HIDUP KEKRISTENAN."

\section{Pokok Masalah}

Dengan melih atlatar belakang di atas maka ada beberapa pokok yang menjadi permasalahan, antara lain; Pertama, Apa yang dimaksud kitab Amsal tentang Takutakan TUHAN? Kedua, Apa saja manfaat yang akan kita peroleh ketika kita hidup Takut akan TUHAN. Ketiga, Bagaimana implementasinya dalam kehidupan kekristenan.

\footnotetext{
${ }^{4}$ Gerald O'collins, SJ \& Edward G. farrugia, SJ, KamusTeologi (kanisius, Anggota IKAPI ), 23.
} 


\section{Tujuan Penulisan}

Pertama, Untuk memaparkan konsep Takut akan TUHAN berdasarkan kitab Amsal. Kedua, Untuk menjelaskan manfaat dari Takutakan TUHAN. Ketiga, Untuk menjelaskan implementasinya dalam kehidupan Kekristenan setiap hari.

\section{Manfaat Penulisan}

Adapun manfaat dari penulisan karya ilmiah ini adalah: Pertama, Untuk menambah wawasan dan pemahaman penulis tentang arti Takut akan TUHAN dalam Kitab Amsal dan mengetahui manfaat-manfaat yang akan diperoleh ketik asetiap orang menerapkan konsep Takut akanTUHAN ini dengan benar. Kedua, Sebagai sarana untuk memberi masukan dan koreksi terhadap cara pandang yang keliru mengenai konsep Takut akan TUHAN dalam kehidupan kekristenan. Ketiga, Sebagai bahan masukan bagi penulis dalam memahami konsep Takut akan TUHAN, secara khusus dalam kitab Amsal. Keempat, Untuk memenuhi salah satu persyaratan dalam menyelesaikan program strata satu (SI) di Sekolah Tinggi Theologia Jaffray Makassar.

\section{Metode Penelitian}

Adapun metode yang digunakan dalam penelitian ini adalah metode kualitatif yaitu metode penelitian Kepustakaan (library research), terhadap berbagai sumber data antara lain: Alkitab, tafsiran-tafsiran kitab Amsal dan buku-buku yang membahas tentang Takut akan TUHAN serta penulis menggunakan metode eksegesis. Yang disusun secara deskriptif untuk mencapai sasaran dan tujuan penulisan.

\section{Batasan Penulisan}

Ruang lingkup pembahasan karya ilmiah ini terbatas pada Kitab Amsal, secara khusus kata Takutakan TUHAN dalam kitab Amsal. Bilamana terdapat kutipan ayat-ayat dari Alkitab atau surat-surat lain sertabuku-buku yang ditulis oleh pakar teologi sehubungan dengan konsep Takutakan TUHAN, itu hanya merupakan referensi perbandingan. 


\section{METODOLOGI PENELITIAN DAN KONSEP KITAB AMSAL TENTANG TAKUT AKAN TUHAN}

Penulisan karya ilmiah ini adalah untuk menjelaskan konsep kitab Amsal tentang takut akan TUHAN, maka ada beberapa garis besar di dalam metodologi penelitian ini yang akan digunakan oleh penulis di dalam menyusun karya ilmiah ini, jenis penelitian, materi dan sumber penelitian, teknik pengumpulan data, dan analisis data. Secara ringkas klarifikasinya adalah sebagai berikut:

\section{Metodologi Penelitian}

Jenis Penelitian

Penulisan karya ilmiah ini menggunakan jenis metode penelitian kualitatif, mengenai konsep kitab Amsal tentang takut akan TUHAN. Penelitian ini secara khusus akan membahas apa konsep kitab Amsal tentang takut akan TUHAN yang mencakup teologi eksegesis dan kajian Alkitab untuk menafsir dan memahami konsep takut akan TUHAN berdasarkan kitab Amsal.

\section{Materi dan Sumber Penelitian}

Dalam penulisan karya ilmiah ini yang menjadi objek utama sumber penelitian yang akan dibahas oleh penulis adalah Alkitab, secara khusus kitab Amsal.

\section{Teknik Pengumpulan Data}

Adapun langkah-langkah atau teknik yang akan penulis gunakan dalam pengumpulan data di dalam penulisan karya ilmiah ini adalah, sebagai berikut:

\section{Konsep Kitab Amsal Tentang Takut Akan TUHAN}

Menurut Kamus Besar Bahasa IndonesiaKonsep adalah "Rancangan atau buram surat, idea atau pengertian yang diabstrakkan dari peristiwa kongkrit, satu peristiwa yang dapat mengandung konsep yang berbeda, gambaran mental dari objek, proses atau apapun yang ada di luar bahasa, yang digunakan oleh akal budi untuk memahami hal-hal lain". 5

Sebelum penulis memaparkan apa konsep kitab Amsal tentang takut akan TUHAN, terlebih dahulu setiap orang harus mengetahui dan mengenal tentang TUHAN atau Allah yang sedang dan akan dibicarakan selanjutnya. Siapakah Dia? Bagaimanakah keberadaan-Nya?Mengapa harus takut terhadap Dia? Apa yang dapat Dia lakukan bagi manusia? Seperti apakah Dia? Pertanyaaan-pertanyaan seperti diatas sangat penting dipertanyakan oleh setiap orang Kristen yang percaya kepada

\footnotetext{
${ }^{5}$ Kamus Besar Bahasa Indonesia, s.v. "Analisis.”
} 
TUHAN. Bahkan masih banyak lagi pertanyaan-pertanyaan penting lainnya. Oleh karena itu, perlu mengenal Dia terlebih dahulu lewat keberadaan diri-Nya sebelum mengetahui konsep tersebut.

\section{Eksistensi Allah}

Untuk mengenal siapakah Allah terlebih dahulu harus tahu siapakah Allah itu?

Dalam Perjanjian Lama ada tiga nama umum yang sering dipakai untuk menyebutkan nama Allah, antara lain: YHWH adalah nama Allah Israel, yang diterjemahkan 'TUHAN' dalam bahasa Indonesia. Adonay adalah gelar (sebutan) yang cocok untuk Allah, yang diterjemahkan 'Tuhan'. Elohim adalah jenis eksistensi yang ilahi, dan kata itu menyatakan bahwa Dia "Allah", bukan manusia, malaikat, atau makhluk yang lain. ${ }^{6}$

Dari ketiga nama di atas, Elohim merupakan nama yang menunjukkan pribadi Allah sebagai Allah bukan manusia atau pun malaikat. Elohim adalah nama yang digunakan untuk menunjukkan keberadaan-Nya sebagai Allah atau nama diri Allah.

Dalam Kamus Teologi God-Ada tertinggi (a) yang harus disembah dan diabdi (Ul 6:4-5) dan (b) yang dalam tradisi monoteis, diyakini sebagai Pencipta yang personal, abadi, tidak berubah, mahatahu dan mahakuasa. Menurut PL, Allah Israel yang satu dan kudus mengatasi dunia material dan tidak boleh digambarkan dalam bentuk apa pun (Kel 20:4; Im 19:4; Ul 4:12.15-24). ${ }^{7}$

Yahweh adalah nama diri Allah, seperti Elohim adalah nama umum bagi Allah. Jadi, pada khususnya Yahweh adalah nama dari Allah yang hidup yang dinyatakan oleh Alkitab. Asal mulanya tidak pasti, meskipun mungkin berasal dari kata dasar ' $h w h$ ' atau 'hyh', yang mengandung pengertian 'eksistensi yang mandiri dan tidak bermuasal'. Allah adalah pribadi yang ada dengan sendirinya. Allah adalah pencipta dari yang tidak ada menjadi ada (bara) bukan membuat yang sudah ada menjadi ada (asa).

Sebutan pertama untuk Allah dalam Alkitab menggunakan nama Elohim: "Pada mulanya Allah [Elohim] menciptakan..."(Kej 1:1). Nama

\footnotetext{
${ }^{6}$ D.L. Baker, Pengantar Bahasa Ibrani (Jakarta: BPK Gunung Mulia, 2008), 53.

${ }^{7}$ Gerald O'Collins, SJ \& Edward G. Farrugia, SJ, Kamus Teologi (Yogyakarta: Penerbit KANISIUS, 1996), 23.

${ }^{8}$ Ensiklopedi Alkitab Masa Kini Jilid I (Yayasan Komunikasi Bina Kasih/OMF, 2002), 33.
} 
untuk Allah tersebut menyatakan Dia sebagai Pribadi Yang Mahatinggi, Pencipta semula, Pribadi yang sempurna, dan sebagai yang Kekal. Kata Ibrani Elohim berasal dari kata El, yang Perkasa atau sang Pencipta, atau alah, yang artinya bersumpah atau mengikat diri sendiri dengan suatu sumpah (yang secara tidak langsung menyatakan kesetiaan). ${ }^{9}$

\section{Allah Mahakuasa}

"Dengan hikmat TUHAN telah meletakkan dasar bumi, dengan pengertian ditetapkan-Nya langit, dengan pengetahuan-Nya air samudera raya berpencaran dan awan menitikkan embun" (Ams. 3:1920).

Kata "Meletakkan dasar bumi" di sini menggunakan kata (Ibrani: "Yacad"). Kata ini menyatakan kemahakuasaan Allah dalam melaksanakan penciptaan-Nya atas bumi ini dan menunjukkan eksistensi Allah sebagai satu-satunya pribadi yang telah meletakkan dasar bumi sejak dari semula. Kata ini juga menunjukkan bahwa pada dasarnya bumi ada karena perbuatan Allah saja. Dengan hikmat-Nya Allah menciptakan langit dan bumi bahkan dengan hikmat yang sama Allah tetap memelihara alam semesta bahkan memberikan kehidupan di dalamnya. Tafsiran Alkitab masa kini memberikan penjelasan, bahwa "Hikmatlah yang menjadi pedoman dasar waktu Allah menciptakan dan tetap menjadi demikian dalam Allah memelihara alam semesta, baik dalam air bah (diingatkan Kej. 7:11) maupun dalam selalu datangnya embun di bumi, dari mana segala sesuatu dapat hidup"10.

Allah dalam Kemahakuasaan-Nya tidak dapat dipahami oleh manusia manapun dengan sempurna siapapun dia tanpa terkecuali. Namun bukan berarti Dia tidak dapat dikenal sekalipun Dia tidak mampu dimengerti oleh manusia secara utuh. "Teologi Reformed percaya bahwa Tuhan dapat dikenal, akan tetapi tidak mungkin manusia dapat memperoleh pengenalan yang lengkap menyeluruh dan sempurna tentang Dia". ${ }^{11}$ Keberadaan-Nya tidak dapat dikenal semata-mata hanya dengan mengandalkan Intelek.Intelek manusia terbatas. c Intelek manusia hanya dapat memahami apa yang dapat dilihat dan dimengerti olehnya, tetapi untuk mengenal Allah intelek tidak mampu.

Nicholas dari Cusa mengatakan, Intelek itu tahu bahwa ia tidak mengenal Engkau (Allah), karena dia tahu bahwa Engkau tidak dapat

${ }^{9}$ Elmer L. Towns, Nama-Nama Allah (Yogyakarta: Yayasan ANDI, 1981), 10-11.

${ }^{10}$ Tafsiran Alkitab Masa Kini 2 (Jakarta: BPK Gunung Mulia, 1976), 305.

${ }^{11}$ Louis Berkhof, Teologi Sistematika l (Lembaga Reformed Injili Indonesia, 1993), 29. 
dikenal kecuali kalau apa yang tidak diketahui dapat diketahui, dan apa yang tidak terlihat dapat dilihat dan apa yang tidak tercapai dapat dicapai. Lebih lanjut dia berkata, "Jika ada seseorang yang mengemukakan suatu konsep yang menggambarkan tentang Engkau, aku tahu bahwa konsep itu bukanlah konsep tentang Engkau, karena setiap konsep itu berakhir pada dinding Firdaus...demikian juga, jika ada seseorang yang mengatakan bahwa ia mengerti tentang Engkau, dan ingin memberikan sesuatu agar mereka dapat mengerti tentang Engkau, orang ini pun jauh daripada mengerti akan Engkau...karena Engkau bersifat mutlak, di luar segala konsep yang mungkin dibentuk oleh manusia. ${ }^{12}$

Dengan memperhatikan keterangan yang dicatat dalam kitab Amsal tersebut, maka segala sesuatu yang telah ada di langit dan di bumi sebagai ciptaan-Nya termasuk manusia sekalipun tetap ada di bawah kedaulatan-Nya. Hal ini dikemukakan oleh Robert Alden, "karena Allah pencipta langit dan bumi dan di bawah pimpinan kedaulatan-Nya semua berada". ${ }^{13}$

Kemahakuasaan Allah yang tidak dapat dipahami ini tidak harus membuat manusia menjauh dan tidak lagi peduli dengan keberadaan Allah, sebab dalam kehidupan manusia masalah akan tetap ada tetapi ketika masalah itu datang tidak ada tempat lain untuk manusia lari dan mencari pertolongan kalau bukan kepada Allah. Kita harus berusaha mengenal Dia dan kuasa-Nya. Tuhanlah satu-satunya yang menjadi tempat sandaran setiap manusia (Ams. 3:26).

Elmer L. Towns berkata,

El Shaddai, Allah Yang Maha Kuasa, adalah sebuah nama yang harus dikenal dan dipercayai setiap orang percaya. Pada waktu kita menghadapi masalah-masalah atau bahaya-bahaya, kita dapat berseru kepada yang Mahakuasa untuk memohon pertolongan-Nya. Ia tidak selalu menyingkirkan masalah-masalah kita atau menyisihkan kita dari badai-badai kehidupan, tetapi ia akan memberi kita kekuatan untuk menghadapinya. ${ }^{14}$

Kemahakuasaan Allah juga mampu mengendalikan semua rencanarencana manusia yang ada dalam dunia ini, manusia bebas menentukkan rencana-rencana yang akan dijalaninya, namun pada akhirnya Tuhanlah satu-satunya pribadi yang berhak untuk mengendalikan semua rencana

\footnotetext{
${ }^{12}$ E.P.Dutton \& Sons Dalam A.W.Tozer, Mengenal Yang Mahakudus (Bandung: Kalam Hidup, 1993), 17.

${ }^{13}$ Robert Alden, Perilaku Yang Bijaksana : Tafsiran Amsal Salomo (Lembaga Reformed Injili Indonesia, 1991), 19.

${ }^{14}$ Elmer L. Towns, Nama-Nama Allah (Yogyakarta: Yayasan ANDI, 1981), 52-53. 
itu (Ams. 16:9). Jadi, Allah bukan hanya berkuasa untuk membentuk dan meletakkan dasar bumi ini, akan tetapi Allah juga berkuasa atas seluruh kehidupan manusia bahkan rencana-rencana manusia pun tetap ada dalam kendali kekuasaan-Nya.

\section{Allah Mahakudus}

"Permulaan hikmat adalah takut akan TUHAN, dan mengenal yang mahakudus adalah pengertian" (Ams. 9:10).

Kudus Ibr. "Kadosy" kt sifat dapat berarti 'terpisah' (dikhususkan) atau 'terpotong dari' digunakan terhadap keadaan terlepasnya seseorang atau suatu benda); (Yunani Hagios) kedua-duanya menunjuk kepada makna yang sama. ${ }^{15}$

Istilah Kudus di PL sama dengan di PB, dipakai dalam pengertian tertinggi terhadap Allah. Istilah itu menunjuk, pertama, kepada keterpisahan Allah dari ciptaan dan bahwa Ia mengungguli ciptaan itu. Demikianlah 'Kudus' menggambarkan transendensi Allah. Yahweh, karena 'kekudusan-Nya' berdiri bertentangan dengan ilahilah (Kel 15:11) demikian juga dengan seluruh ciptaan (Yes 40:25). ${ }^{16}$

Allah dikatakan Mahakudus berarti bahwa, kesempurnaan Allah dengan mana sejak kekal mempertahankan keagungan moral-Nya sehingga Ia menentang dosa dan menuntut kesucian dari mahlukmahluk-Nya. ${ }^{17}$

Dari pengertian di atas, dapatlah diketahui bahwa Allah sebagai yang Mahakudus merupakan satu pribadi yang tidak dapat disamakan dengan manusia, sebab Dia dalam eksistensinya sebagai Allah yang mahakudus telah dipisahkan, dikhususkan. Keberadaan-Nya benarbenar bersih dari cela dan noda."Kekudusan merupakan sifat yang terutama diantara semua sifat Allah". ${ }^{18}$

Allah sebagai pribadi yang Kudus menyatakan diri-Nya sebagai Allah yang sama sekali tanpa dosa dan benar sama sekali (Im 1l:44-45; Mzm 85:14; 145:17; Mat 5:48). Adam dan Hawa diciptakan tanpa dosa (bd. Kej 1:31) tetapi dengan kemampuan untuk berbuat dosa.Pada pihak lain, Allah tidak dapat berbuat dosa (Bil 23:19; 2Tim 2:13; Tit 1:2; Ibr 6:18). Kekudusan-Nya juga mencakup pengabdian-Nya untuk melaksanakan maksud-maksud dan rencana-Nya. ${ }^{19}$

${ }^{15}$ Ensiklopedi Alkitab Masa Kini Jilid I (Yayasan Komunikasi Buna Kasih/OMF, 2002), 617.

${ }^{16}$ Ensiklopedi Alkitab Masa Kini Jilid I (Yayasan Komunikasi Buna Kasih/OMF, 2002), 617.

${ }^{17}$ Sekolah Tinggi Theologia Injili Indonesia (Yogyakarta: STII, 1996), 78.

${ }^{18}$ William Dyrness, Tema-Tema Dalam Toelogi Perjanjian Lama (Malang: Gandum Mas, 1990), 36.

${ }^{19}$ Alkitab Penuntun Hidup Berkelimpahan (Malang: Gandum Mas, 2000), 947. 
Allah yang Kudus juga memberikan pengudusan kepada umatNya. Pengudusan tersebut telah Allah lakukan bagi orang Israel dalam masa PL. Pengudusan adalah kehendak Allah bagi orang Israel dalam PL; seharusnya mereka menjalankan hidup yang suci dan dikuduskan, dipisahkan dari gaya hidup bangsa-bangsa disekeliling mereka (Ams.1:10-19). Demikian juga sebagai orang Kristen pada zaman ini sebagai orang-orang yang telah dipilih dan dikhususkan oleh-Nya dituntut untuk hidup dalam kekudusan dan memisahkan diri dari gaya hidup duniawi yang ada disekitarnya.

Orang yang kudus tidak memanjakan diri sendiri. Mereka tidak mengizinkan keinginan-keinginan dan rasa cinta yang salah atau kecendurunagan yang immoral menguasai hidup mereka. Tuhan Yesus sendiri memperingatkan para pengikut-Nya, "jagalah dirimu, supaya hatimu jangan sarat oleh pesta pora dan kemabukan serta kepentingan-kepentingan duniawai" (Luk 21:34). (Dan pada peringatan ini tanpa diragukan lagi dapat diterapkan pada perilaku seksual yang tidak wajar, alkohol, obat-obatan terlarang, atau apa saja yang membuat orang kecanduan - Ed.). ${ }^{20}$

Kekudusan bukanlah sekadar salah satu atribut Allah. Kekudusan merupakan natur esensial Allah dan tercermin dalam semua atributNya. Hikmat-Nya adalah hikmat yang kudus. Keindahan-Nya adalah keindahan yang kudus. Kemuliaan-Nya adalah kemuliaan yang kudus. Kekudusan-Nya "melengkapi kesempurnaan-Nya dengan kemuliaan, kemasyhuran dan keselarasan. ${ }^{21}$

Kekudusan Allah tidak ada yang bisa mengerti dan memahaminya dengan sempurna. Kekudusan Allah mutlak ada pada diri-Nya sendiri dan tidak ada suatu standar apapun yang dapat disesuaikan dengan kekudusan-Nya.

\section{Allah Mahahadir}

"Kutuk TUHAN ada di dalam rumah orang fasik, tetapi tempat kediaman orang benar diberkati-Nya. Apabila Ia menghadapi pencemooh, maka Ia pun mencemooh, tetapi orang yang rendah hati dikasihani-Nya. Orang yang bijak akan mewarisi kehormatan, tetapi orang yang bebal akan menerima cemooh" (Ams. 3:33-35 bdg 8:1-6 bdg 15:3).

\footnotetext{
${ }^{20}$ Ibid, 24.

${ }^{21}$ John M'Clintock \& James Strong dalam Edward T. Welch, Ketika Manusia Dianggap Besar dan Allah Dianggap Kecil (Surabaya: Momentum Christian Literature, 2003), 109-110.
} 
Kata "ada di dalam rumah" di sini menggunakan kata (Ibr: "Bayith"). Kata ini menunjukkan kehadiran Allah di dalam rumah setiap orang, baik orang fasik maupun tempat kediaman orang benar. Kehadiran Allah dinyatakan atas semua orang.Allah tidak hanya hadir di rumah orang benar tetapi Allah pun hadir untuk menyelidiki kediaman orang fasik. Bagian ini menjelaskan kepada setiap manusia bahwa Allah tidak membedakan setiap orang di bumi ini, kehadiran-Nya tidak ditentukkan oleh keadaan manusia, Dia dapat hadir di rumah orang fasik dan orang benar untuk menghakimi. Dia bukan hanya mengawasi rumah orang benar tetapi Dia juga terlibat langsung atau hadir di rumah itu secara langsung untuk memberkatinya.

Kehadiran Allah itu amat besar. Dia tidak dapat dimuat. Kehadiran Allah juga berbeda dalam arti seluruh kehadiran-Nya ada dimanamana. Dia tidak bisa dibagi-bagi. Setiap bagian kecil alam semesta mengandung kehadiran Allah yang utuh. Kita mengetahui hal ini karena Allah yang mempunyai apa yang ahli teologi sebut sebagai ketunggalan Allah. Yaitu, Dia tidak bisa dibagi-bagi. ${ }^{22}$

Setiap orang Kristen yang percaya akan keberadaan Allah sebagai Allah yang Mahahadir pasti akan mengerti apa yang dimaksud dengan Takut akan TUHAN, sebab setiap orang yang menyadari keberadaan Allah sebagai pribadi yang Mahahadir tidak akan pernah melakukan halhal yang tidak benar sekalipun itu mungkin tidak kelihatan oleh oranglain karena kesadarannya akan kehadiran Allah setiap saat disetiap langkah kehidupan yang dijalani setiap hari. Kitab amsal dengan jelas berkata, bahwa mata TUHAN ada di segala tempat untuk mengawasi orang yang jahat maupun orang yang baik (Ams. 15:3). Ini berarti bahwa Allah hadir di segala tempat tanpa terkecuali untuk mengawasi segala yang manusia lakukan dalam dunia ini. Hanya orang bebal yang tidak pernah mengakui akan keberadaan Allah sebagai Allah yang Mahahadir (Mzm. 14:1).

Keberadaan Allah sebagai oknum yang Mahahadir tidak dibatasi oleh apapun. Tidak ada satupun manusia yang dapat bersembunyi atau lari dari hadapan Allah. Dia ada dimana-mana sekalipun manusia berada di tempat yang tersembunyi Allah tetap ada dan mengawasi kehidupannya (Ams. 15:3; Yer. 23:23-24; Maz. 139:7-12). Allah dapat hadir di manapun dan kapanpun Dia mau, sekalipun manusia terkadang melakukan kesalahan dan ingin bersembunyi dari manusia lainnya, namun harus disadari bahwa ternyata Allah tidak akan pernah dapat dikelabui oleh siapa pun di bumi ini. Terkadang manusia berpikir bahwa Allah tidak melihat dan mengetahui apa yang dilakukannya,

\footnotetext{
${ }^{22}$ Tony Evans \& Moody Press, Teologi Allah: Allah Kita Maha Agung (Malang: Gandum Mas, 1999), 172.
} 
bahkan tidak jarang manusia lebih takut terhadap manusia daripada Allah. Manusia lebih memilih takut kepada sesamanya manusia daripada terhadap Allah yang secara riil hadir dan berkuasa dalam setiap kehidupannya.

Edward T. Welch mengatakan,

Takut akan manusia adalah sesuatu yang kita lakukan secara alamiah. Semenjak kejatuhan manusia ke dalam dosa, takut akan manusia telah menjadi naluri manusiawi kita. Namun tragisnya, hati kita mempunyai mitra dalam mengembangkan kecendurungan berdosanya. Dunia beserta segala asumsinya yang tidak alkitabiah justru menguatkan kecendurungan untuk takut atau gentar kepada sesama manusia. ${ }^{23}$

Manusia tidak dapat menyangkal akan kedekatan Allah dengan manusia dan keterlibatan-Nya secara langsung dalam kehidupan manusia, Tony Evans dan Moody Press mengatakan, "Allah begitu dalam terlibat dan senantiasa hadir dalam hidup anda; karena itu Dia tahu apa yang terjadi pada diri anda. ${ }^{24}$ Allah sesuai dengan keberadaan-Nya sebagai oknum yang Mahahadir selalu mendekatkan diri-Nya kepada semua manusia. Bagaimanapun pandangan manusia tentang keberadaan Allah, Dia tetaplah Allah yang melibatkan diri terhadap seluruh aspek kehidupan manusia. John M. Frame mengatakan, "Kehadiran Allah bukanlah sesuatu yang kita temukan melalui ketajaman pikiran secara teoritis. Sebaliknya, kedekatan Allah dengan ciptaan-Nya itu tidak dapat dihindari. Kita selalu memiliki keterlibatan dengan Dia. Karena itulah pengetahuan akan Allah juga merupakan pengetahuan antar pribadi". 25

Pada saat manusia kesepian Allah hadir. Saat manusia jatuh dalam berbagai macam pencobaan Allah hadir. Saat manusia dalam ketakutan Allah hadir. Saat manusia dalam kebingungan Allah hadir. Allah hadir kapanpun manusia membutuhkan-Nya dan dalam situasi apapun juga Dia ada dan hadir disana.

\section{Allah Mahatahu}

"Karena segala jalan orang terbuka di depan mata TUHAN, dan segala langkah orang diawasi-Nya; dunia orang mati dan kebinasaan terbuka dihadapan TUHAN, lebih-lebih hati anak manusia!; siapa bersih

\footnotetext{
${ }^{23}$ Edward T. Welch, Ketika Manusia Dianggap Besar dan Allah Dianggap Kecil (Surabaya: Momentum Christian Literature, 2003), 79.

${ }^{24}$ Tony Evans, Teologi Allah: Allah Kita Maha Agung (Malang: Gandum Mas, 1999), 120.

${ }^{25}$ John M. Frame, Doktrin Pengetahuan Tentang Allah (Malang: Departemen Literatur Saat, ), 26.
} 
kelakuannya, aman jalannya, tetapi siapa berliku-liku jalannya, akan diketahui" (Ams. 5:21; 15:11 bdg 10:9).

Dalam bahasa Inggris"omniscience," ('omni' berarti 'semua' dan 'science' berkaitan dengan 'pengetahuan'). "Kemahatahuan Allah berarti bahwa sama sekali tidak ada sesuatu pun yang tidak diketahui-Nya; bahwa tidak ada suatu sistem informasi atau rangkaian data manapun yang bisa ada diluar pengetahuan Allah - tak satupun. Dia tidak bergantung kepada siapa pun di luar Dia, untuk pengetahuan apapun dan tentang apapun". ${ }^{26}$ Sehubungan dengan Kemahahadiran Allah dalam seluruh aspek kehidupan manusia sangat berkaitan erat dengan Kemahatahuan Allah. Allah mengetahui segala sesuatu baik yang ada dalam pikiran, perasaan, bahkan hati manusia bahkan Allah lebih mengenal manusia daripada manusia itu sendiri. Kemahatahuan Allah mengungkapkan segala aspek kehidupan manusia tidak ada satupun yang Dia tidak ketahui dalam diri manusia. Kemahahadiran Allah dalam hidup manusia secara otomatis juga mengungkapkan kemahatahuan Allah, bukan hanya apa yang dilakukan manusia yang kelihatan dari luar yang diketahui oleh Allah tetapi secara menyeluruh sampai ke dalam lubuk hati manusia oleh karena Roh manusia adalah pelita TUHAN yang akan menyelidiki seluruh lubuk hati manusia (Ams. 20:27). Allah pun tahu bahkan belum dilakukan masih dalam perencanaan dan masih dipikirkan Allah pun tahu. Kalau demikian apa yang manusia bisa lakukan yang tidak ingin diketahui oleh Allah? Tidak ada satupun sesuatu yang harus disembunyikan dari Dia, sebab Dia adalah Allah yang dapat menyelidiki setiap manusia baik saat dia bangun, jalan, duduk ataupun berdiri.

Keberadaaan-Nya bukan seperti yang oleh kebanyakan orang ketahui. Banyak orang menyangka bahwa Allah itu jauh dari manusia (Transenden), Dia tidak dapat dijangkau oleh manusia. Manusia merasa Allah yang jauh itu tidak dapat hadir dan dekat dengan manusia, bahkan Dia tidak mengetahui apa-apa tentang manusia sedikitpun. "Golongan Teisme selalu percaya pada Allah yang transenden sekaligus imanen, sedangkan golongan Deisme menyingkirkan Allah dari dunia dan menekankan ketransendenan Allah dengan akibat penyingkiran keimanenannya". ${ }^{27}$

Allah tahu apa yang manusia lakukan di depan umum untuk diketahui oleh semua orang, Allah juga tahu apa yang dilakukan manusia secara pribadi yang tidak ingin diketahui oleh orang banyak, bahkan Allah tahu motivasi setiap orang melakukan sesuatu. Allah tahu akan

\footnotetext{
${ }^{26}$ Tony Evans, Teologi Allah: Allah Kita Maha Agung (Malang: Gandum Mas, 1999), 150.

${ }^{27}$ Louis Berkhof, Teologi Sistematika:Doktrin Allah (Surabaya: Lembaga Reformed Injili Indonesia, 1993), 17.
} 
menjadi apa manusia kedepannya, Allah tahu segala apa yang manusia miliki. Tidak ada satupun yang tersembunyi dihadapan Allah, semuanya telanjang dihadapan-Nya, segala sesuatunya Allah ketahui.

Pengetahuan Allah bersifat Intuitif (bersifat secara intuisi, berdasar bisikan gerak hati). Ketika Anda duduk di gereja, Dia tahu, anda lebih suka berada disuatu tempat lain. Dia tahu rencana anda bila anda keluar dari gereja. Dia selalu sungguh mengetahui dengan baik segala data yang menyangkut semua manusia di manapun. Pengetahuan-Nya bersifat intuitif. ${ }^{28}$

Kalau manusia menyadari akan keberadaan Allah yang Mahatahu ini dengan benar, maka semua hal yang menyangkut kehidupannya, gerak-geriknya dan semua yang dilakukannya berdasarkan Takut akan TUHAN, sehingga segala sesuatu yang buruk dan tidak memuliakan TUHAN tidak akan pernah menjadi kesukaannya.

\section{Definisi Takut akan TUHAN}

"Takut akan TUHAN adalah permulaan pengetahuan, tetapi orang bodoh menghina hikmat dan didikan". (Ams. 1:7)

Alkitab menggunakan beberapa kata untuk mengartikan takut atau ketakutan. Yang paling umum ialah Ibrani "yir'a" dan "pakhad" Yunani "fobos". "Secara teologis dapat dikemukakan empat yang utama; ketakutan yang kudus, takut diperbudak, takut kepada manusia, dan yang disegani".

Takut akan TUHAN berarti merasa gentar (ngeri) atau segan terhadap yang Mahatinggi, Mahamulia, Mahakudus, dan Mahakuasa. "takutakan TUHAN merupakan ketakutan yang kudus, dimana sikap ini adalah dampak dari pengenalan orang percaya akan Allah yang hidup". 30

Takut dalam arti 'perasaan takut', maupun 'ketakutan yang amat sangat'. Dalam Luk. 21:1l, TB LAI memilih kata 'mengejutkan'. Namun, dalam Ibr. 10:31, TB LAI menterjemahkan 'ngeri'. ${ }^{31}$

Ada banyak hal yang seringkali membuat manusia mengalami rasa takut seperti takut akan kegelapan. Takut akan kematian. Takut akan ketinggian. Takut akan kehilangan orang-orang yang dicintai dan banyak lagi jenis ketakutan lainnya. Sebagian bahkan membutuhkan terapi untuk mengatasi semua rasa takut tersebut. Takut akan TUHAN bukan seperti itu.

\footnotetext{
${ }^{28}$ Tony Evans, Teologi Allah: Allah Kita Maha Agung (Malang: Gandum Mas, 1999), 152.

${ }^{29}$ Ensiklopedi Alkitab Masa Kini Jilid II, (Yayasan Komunikasi Bina Kasih/OMF, 1995), 438-439.

${ }^{30} \mathrm{Ibid}$.

${ }^{31}$ W.R.F. Kamus Alkitab, (Jakarta: PT.BPK. Gunung Mulia, 2007), 434.
} 
Perintah yang seringkali diberikan kepada umat Allah dalam PL ialah untuk "takut akan Allah" atau "takut akan TUHAN." Pentinglah untuk memahami apa yang dimaksudkan perintah ini bagi kita selaku orang percaya. Hanya waktu kita sungguh-sungguh takut akan Tuhan, kita akan dibebaskan dari perbudakan kepada semua bentuk ketakutan yang tidak wajar dan keji. ${ }^{32}$

Takut akan Tuhan adalah kesadaran akan kekudusan, keadilan dan kebenaran-Nya sebagai pasangan terhadap kasih dan pengampunanNya, yaitu: mengenal Dia dan memahami sepenuhnya siapakah Dia (bd. Ams 2:5). Takut akan Tuhan berarti memandang Dia dengan kekaguman dan penghormatan kudus serta menghormati-Nya sebagai Allah karena kemuliaan, kekudusan, keagungan, dan kuasa-Nya yang besar (Flp 2:12). ${ }^{33}$

Takut akan TUHAN adalah wujud ketakutan yang sehat. Artinya manusia menghormati Dia, patuh dalam penghakiman-Nya atas dosadosa, berpegang pada Dia, mengenali Dia sebagai TUHAN yang Absolut dan memuliakan-Nya. Takut akan TUHAN akan membawa manusia lebih dekat kepada TUHAN, bukan menjauh dari-Nya. Orang-orang Kristen yang percaya kepada TUHAN memilki rasa takut yang berbeda dengan rasa takut yang dimiliki oleh orang di luar TUHAN. Rasa takut yang dimiliki oleh orang percaya lebih mengarah kepada "penghormatan" akan Dia bukan takut karena adanya suatu "hukuman" yang akan diterimanya. Banyak orang Kristen mempunyai persepsi yang salah tentang arti takut akan TUHAN. Kebanyakan orang Kristen mendefinisikan takut akan TUHAN dengan ketaatan melakukan perintah TUHAN karena rasa takut akan hukuman padahal rasa takut akan TUHAN yang benar harus lahir karena hubungan bukan karena rasa takut akan hukuman, seharusnya takut akan TUHAN bukan karena takut TUHAN marah bila kita tidak taat melainkan kita takut karena kita mengasihi Dia.

Kata takut akan TUHAN digunakan 19 kali di dalam kitab Amsal (Ams. 1:7,29; 2:5; 3:7; 8:13; 9:10; 10:27; 14:2,26,27; 15:16,33; 16:6; 19:23; 22:4; 23:17; 24:21; 28:14; 31:30).

Kata 'takut' dalam kitab Amsal menggunakan kata "yara" dan "yir'a" yang berasal dari kata dasar "yare" yang berarti 'takut' atau 'menakuti'. Dalam bahasa inggris digunakan kata 'fear' sebuah kata benda yang ketika berubah menjadi kata kerja, maka kata ini mengacu

\footnotetext{
${ }^{32}$ Alkitab Penuntun Hidup Berkelimpahan (Malang: Gandum Mas, 2000), 286.

${ }^{33}$ Ibid.
} 
kepada suatu sikap segan terhadap Allah. Alkitab Bahasa Indonesia Sehari-hari memberikan penjelasan yang lebih mudah dipahami, "untuk memperoleh ilmu sejati, pertama-tama orang harus mempunyai rasa hormat dan takut kepada TUHAN."(BIS)

l. Kata 'yare YHWH' dalam kitab Amsal menggambarkan suatu sikap 'hormat atau segan' terhadap TUHAN, yang harus diaplikasikan oleh setiap orang dalam kehidupannya setiap hari. Robert Alden mengatakan bahwa, "Terjemahan 'takut' di sini sebenarnya tidak berkonotasi negatif, malah seharusnya merupakan sebuah sikap yang positif terhadap Tuhan. Kalau kita sudah berbuat salah maka kita patut takut, tetapi kalau hubungan dengan Tuhan baik, maka istilah yang lebih baik adalah hormat". ${ }^{34} \mathrm{C}$. Hassell Bullock berkata, "The phrase "fear of the Lord" capsulates the totality of man's religious faith. It is not merely the emotion of fear, nor do the terms awe and reverence exhaust its meaning. It is a comprehensive term for the worship of the Lord, or religion". ${ }^{35}$ Yir'e (Noun, Feminim, singular, genetif of Yir'a or (Pr.31:30). ${ }^{36}$ Dalam bahasa inggris digunakan kata, Fear, noun panic etc. caused by impending danger, pain, etc; cause of this; alarm, dread. Verb be afraid of; feel anxiety about; dread. Verb be afraid of; (for) feel anxiety about; dread; shrink from; revere (God). ${ }^{37}$ Takut, kata benda dll. Panik disebabkan oleh bahaya yang akan datang, nyeri, dll; penyebab ini, alarm, ketakutan. Kata kerjatakut; merasa cemas tentang; ketakutan. Kata kerja takut, (untuk) merasa cemas tentang, takut, segan, memuja (Allah).

2. Pengertian 'takut' dalam kitab Amsal berbeda dengan pengertian takut yang seringkali dialami oleh setiap manusia, seperti takut ular, takut ketinggian, takut gelap dan sebagainya. Pengertian takut disini adalah sehubungan dengan praktek hidup sehari-hari yang dekat dengan TUHAN dengan cara menjauhi kejahatan. Kitab amsal mendefinisikan takut akan TUHAN sebagai berikut: Pertama(l:7) "takut akan TUHAN" adalah permulaan pengetahuan (bdg. 1:29; 9:10; 15:33 Ayb. 28:28; Mzm. 111:10). Kedua $(2: 4,5)$ "takut akan TUHAN" digambarkan seperti harta terpendam. Ketiga (8:13) "takut akan TUHAN" ialah membenci kejahatan (bdg. 3:7; 16:6). Keempat (10:27) "takut akan TUHAN" akan memperpanjang umur. Kelima $(14: 2,26,27)$ orang yang berjalan dalam

\footnotetext{
${ }^{34}$ Robert Alden, Perilaku Yang Bijaksana : Tafsiran Amsal Salomo (Lembaga Reformed Injili Indonesia, 1991), 4.

${ }^{35} \mathrm{C}$. Hassell Bullock, An Intoduction To The Old Testament Poetic books (America: The Moody Bible Institute, 1979), 52.

${ }^{36}$ Benjamin Davidson, "The Analytical Hebrew And Chaldee Lexicon."

${ }^{37}$ Oxford Dictionary (New York: Maurice Waite, 1994), 231.
} 
kejujuran adalah orang yang "takut akan TUHAN" (ayt 2; bdg. 23:17), dalam "takut akan TUHAN" ada ketenteraman yang besar (ayt 26; bdg. 15:16; 28:14), "takut akan TUHAN" adalah sumber kehidupan (ayt 27; 19:23; 22:4). Keenam (31:30) isteri yang "takut akan TUHAN" dipuji-puji.

Banyak orang Kristen mempunyai persepsi yang salah tentang arti takut akan TUHAN. Kebanyakan orang Kristen mendefinisikan takut akan TUHAN dengan ketaatan melakukan perintah Tuhan karena rasa takut akan hukuman. "Takut akan TUHAN bukanlah sebuah karunia tetapi merupakan sebuah pilihan (Amsal 1:29). Kitab Amsal menyamakan hal takut akan TUHAN dengan pengetahuan akan Allah (Amsal 2:5-6)" ${ }^{38}$

3. Kata takut akan TUHAN dalam kitab Amsal mengacu kepada praktek hidup sehari-hari untuk lebih lagi mengenal dan berusaha untuk mencari TUHAN dalam kehidupan ini agar kehidupan yang setiap orang jalani sekarang ini bahkan selama hidup tidak dijalaninya dengan sia-sia, tetapi senantiasa dijalaninya dalam takut akan TUHAN. C. Hassell Bullock mengatakan, bahwa banyak orang yang dipengaruhi oleh suatu pendekatan teoritis terhadap kekristenan mampu mendapat "pegangan" tentang iman dengan membaca kitab Amsal. Ia menyentuh berbagai kepentingan bersama dari semua orang yang dikaruniai kehidupan serta yang berjuang bagaimana menjalaninya. ${ }^{39}$ Dilihat dari bentuknya yang imperfek, maka kata takut akan TUHAN merupakan salah satu pekerjaan yang belum selesai dilakukan dan masih terus berlangsung sampai sekarang. Ini adalah suatu perintah yang harus dijalankan oleh setiap orang percaya. Sesuai denganarti dari kata takut (yare) 'takut' atau 'menakuti,' berarti mengacu kepada 'takut' atau 'menakuti' suatu objek yang lebih besar dalam hal ini (TUHAN). Ini merupakan perasaan takut secara positif karena, kata 'takut' disini membawa orang kepada sesuatu yang lebih baik. Membawa orang kepada pengetahuan yang lebih baik akan siapa TUHAN atau objek yang perlu ditakuti itu. Perasaan takut yang demikian yang perlu dimiliki oleh setiap orang yang mengaku percaya kepada TUHAN sehingga, memiliki pengetahuan yang benar tentang segala sesuatu yang setiap orang lakukan dan jalani selama hidup.

4. Kitab Amsal memberikan pengajaran tentang bagaimana sikap setiap orang dalam menjalani kehidupan sehari-hari yang senantiasa harus difokuskan kepada pengenalan akan TUHAN sehingga, ketika setiap orang memperoleh pengenalan akan TUHAN secara benar, maka

\footnotetext{
${ }^{38}$ Andrew E. Hill \& John H. Walton, Survei Perjanjian Lama (Malang: Gandum Mas, 1996), 472.

${ }^{39} \mathrm{C}$. Hassell Bullock, Kitab-Kitab Puisi Dalam Perjanjian Lama (Malang: Gandum Mas, 2003), 199.
} 
sikap takut akan TUHAN akan selalu menjadi gaya hidup setiap orang. Pengajaran dalam Amsal ini bukan saja hanya ditujukan kepada orangorang percaya saja, tetapi juga mencakup seluruh masyarakat secara umum.

Dalam Kitab Amsal yang mendasari kehidupan seseorang ialah hubungannya dengan Allah. Dari hubungan itulah tumbuh pengetahuan moral serta kemampuan untuk menilai apa yang benar (2:6-22), sikap yang tepat (pantas) terhadap harta benda (3:9-10), bekerja dengan rajin (6:6-11), perlunya keseimbangan serta rasa aman hidup di dunia ini (3:21-26), dan hubungan yang benar dengan sesama $(3: 27-29){ }^{40}$

Takut akan TUHAN merupakan motto kitab Amsal. Takut akan TUHAN mengarahkan setiap orang kepada kehidupan yang lebih bermanfaat. Dalam menjalani kehidupan, setiap orang dituntut untuk selalu takutakan TUHAN.Dalam kitab Amsal sangat jelas digambarkan bagaimana keadaan orang-orang yang memilih takut akan TUHAN dengan keadaan hidup orang-orang yang memilih untuk mengabaikan TUHANdalam hidupnya (Ams. 10:27; 14:2,26,27; 15:16). Penulis kitab Amsal memberikan nasihat kepada setiap anak-anak muda untuk lebih mendengarkan didikan dan menjauhi segala jalan orang-orang berdosa disekitarnya.Penulis dalam hal ini Salomo memberikan teguran kepada orang-orang bodoh atau bebal untuk lebih memilih pengetahuan daripada tetap berada pada keadaan mereka yang tidak mau mengenal TUHAN, dan menolak didikan dan pengetahuan dan lebih memilih untuk tetap ada diposisi mereka semula (Ams. 1:7; 2:29). Dalam dunia ini, kehidupan setiap orang diperhadapkan kepada banyak persoalan, tantangan, godaan, dan hambatan.Tanpa terkecuali setiap orang Kristen pun menghadapi hal ini. Oleh sebab itu, diperlukan suatu keterampilan untuk menghadapi kehidupan tersebut, dan kitab Amsal lebih tepat memberikan solusi untuk menghadapi kehidupan dan segala persoalan yang ada di dalamnya yaitu dengan memilih "takut akan TUHAN. "untuk memperoleh ilmu sejati, pertama-tama orang harus mempunyai rasa hormat dan takut kepada TUHAN"(BIS). Terjemahan Alkitab Bahasa Indonesia Sehari-hari, lebih tepat mengungkapkan perasaan takut yang sebenarnya harus dimiliki oleh setiap orang terhadap TUHAN, yaitu menghormati Dia, bukan takut untuk dihukum tetapi takut karena manusia menghormati Dia sebagai TUHAN yang besar. Orang-orang yang mengenal dan memilih takut akan TUHAN tidak

${ }^{40}$ C. Hassell Bullock, Kitab-Kitab Puisi Dalam Perjanjian Lama (Malang: Gandum Mas, 2003), 202. 
perlu memiliki perasaan cemburu ataupun iri terhadap kejahatan orangorang yang ada disekitarnya, bahkan tidak perlu mengikuti jalan-jalan tersebut, Karena jalan hidup orang-orang yang takut akan TUHAN telah diatur oleh TUHAN sendiri baginya (Ams. 3:3135). Ada banyak orang di dunia ini yang dengan sesuka hatinya melakukan apa saja yang diinginkan hatinya tidak peduli apakah itu baik atau tidak.

5. Pada intinya, kitab Amsal mengajarkan bahwa, kehidupan yang setiap orang jalani di dunia ini, segala sesuatu yang dilakukan harus berdasarkan takut akan TUHAN, karena kehidupan ini sepenuhnya ada dalam kendali dan pengawasan TUHAN semata. Relasi manusia dengan TUHANnya akan menentukkan bagaimana hidupnya kedepan.

\section{Manfaat dari Takut akan TUHAN Hikmat}

"Takut akan TUHAN adalah didikan yang mendatangkan hikmat, dan kerendahan hati mendahului kehormatan; Permulaan hikmat adalah takut akan TUHAN, dan mengenal yang mahakudus adalah pengertian" (Amsal. 9:10; 15:33).

Amsal 15:33..."takut akan TUHAN adalah didikan yang mendatangkan hikmat, dan kerendahan hati mendahului kehormatan...".Dalam terjemahan (BIS) mengatakan, "takut akan TUHAN adalah dasar pendidikan yang baik", berarti bahwa seseorang akan berhikmat atau seseorang yang akan memiliki hikmat harus didasarkan atau berlandaskan takut akan TUHAN.

Hikmat merupakan manfaat terbesar yang pernah dimiliki oleh manusia menurut kitab amsal.bahkan salah satu penulis dari kitab Amsal tersebut merupakan orang yang paling berhikmat. Firman Tuhan mencatat dalam 1 Raja-Raja 3:12 demikian, “...maka sesungguhnya Aku melakukan sesuai dengan permintaanmu itu, sesungguhnya Aku memberikan kepadamu hati yang penuh hikmat dan pengertian, sehingga sebelum engkau tidak ada seorangpun seperti engkau, dan sesudah engkau takkan bangkit seorangpun seperti engkau..."Hikmat yang dimiliki oleh Raja Salomo melebihi hikmat yang dimiliki oleh orang-orang pada zamannya, bahkan hikmat yang ada padanya tersebut tidak dapat dimiliki oleh siapapun juga baik sebelum dia ada maupun sesudahnya.

Hikmat merupakan hal utama yang harus kita cari (1:20-23; 2:1-22; 3:1-35; 4:1-27; 8:1-36; 22:17-24:34). ${ }^{41}$ Hikmat merupakan salah satu wujud dari kemahahadiran Allah dalam dunia dan bekerja melalui setiap manusia yang ada di dunia ini. C. Hassell Bullock mengatakan, "tanpa

\footnotetext{
${ }^{41}$ John Balchin dkk, Intisari Alkitab Perjanjian Lama (Jakarta: Persekutuan Pembaca Alkitab, 2005), 145.
} 
hikmat itu maka dunia dan kehidupan manusia tidak akan memiliki makna. Hikmat merupakan kemahahadiran Allah yang menembus alam semesta dan tatanan kemasyrakatan manusia (Ams. 2:1-15; 8:22). Hikmat merupakan cara Allah berbicara, yang tertulis dalam alam dan pengalaman manusia." ${ }^{42}$

Setiap orang harus memiliki hikmat dan mengejar hikmat. Terkadang penulis kitab Amsal juga menggambarkan hikmat seperti suatu pribadi yang dapat bergerak, berteriak, berdiri, bahkan berbicara kepada setiap orang-orang yang ada di jalan-jalan, di lorong-lorong dan di lapangan-lapangan (Ams. 1:20-33 bdg Yer.5:1).

Hikmat sangat dibutuhkan oleh setiap orang untuk menjalani kehidupannya dalam dunia ini. Oleh karena itu, hanya orang-orang yang berhikmat yang akan mampu menjalani dan menata kehidupan dengan baik dan benar. Hanya hikmat yang akan membawa setiap orang menuju kepada kehidupan yang sukses. Jerry Falwell mengatakan, "He is the One you need to guide you. You cannot be successful without His complete leadership in your life." ${ }^{33}$ Hikmat dan takut akan TUHAN merupakan hal yang tidak dapat dipisahkan. Bila kita ingin mempunyai hikmat maka kita harus mempunyai dulu rasa takut akan TUHAN. Ketika kita memilih untuk hidup takut akan TUHAN maka hikmat ilahi akan kita dapatkan bila kita mencarinya dan mengejarnya seperti mencari harta terpendam (Amsal 2:4-5).

\section{Pengetahuan}

"Takut akan TUHAN adalah permulaan pengetahuan, tetapi orang bodoh menghina hikmat dan didikan." (Amsal. 1:7); "Oleh karena mereka benci kepada pengetahuan dan tidak memilih takut akan TUHAN." (Amsal 1:29)

R.E. Harlow mengatakan bahwa, "Ada banyak dalam Amsal tentang bagaimanpun untuk mendapatkan hikmat. Hal pertama adalah untuk mendapatkan pengetahuan dan hal pertama untuk belajar adalah takut akan TUHAN. Takut akan TUHAN juga merupakan awal dari kebijaksanaan.."44 Lebih lanjut Harlow mengatakan, "Mereka membenci pengetahuan yang akan membawa mereka untuk takut akan TUHAN". 4 Jadi, jelaslah dari apa yang dikatakan oleh R.E. Harlow bahwa, dengan pengetahuan manusia akan dapat pengenalan yang benar akan ALLAH

\footnotetext{
${ }^{42}$ C. Hassell Bullock, Kitab-Kitab Puisi Dalam Perjanjian Lama (Malang: Gandum Mas, 2003), 30.

${ }^{43}$ Jerry Falwell, Wisdom For Living (America: SP Publications, Inc, 1984), 45.

${ }^{44}$ R.E. Harlow, Proverbs The King's Wisdom (Canada: Everyday Publications Inc, 1984), 10.

${ }^{45}$ Ibid, 12 .
} 
dan setiap orang yang tidak suka atau membenci pengetahuan secara langsung mereka tidak akan memiliki sikap takut akan TUHAN.

Dalam Alkitab pengetahuan bukanlah sekedar pemahaman intelektual. Pengetahuan mencakup emosi dan hubungan-hubungan personal. Bangsa Israel mempunyai pengetahuan tentang Allah atau pengenalan akan Allah yang tidak dimiliki bangsa-bangsa lain (Yer. 10:25; Yes. 37:20). ${ }^{46}$

Pengetahuan sejati hanya akan didapatkan oleh manusia ketika manusia mempunyai rasa takut akan TUHAN, karena TUHAN itu sendiri adalah sumber pengetahuan sejati yang diperlukan oleh setiap manusia.

Notoatmojo mengatakan,

Pengetahuan adalah merupakan hasil dari "tahu" dan ini terjadi setelah orang melakukan penginderaan terhadap suatu objek tertentu. Penginderaan terjadi melalui panca indera manusia, yaitu: indera penglihatan, pendengaran, penciuman, rasa dan raba. Sebagian besar pengetahuan manusia diperoleh melalui pendidikan, pengalaman oranglain, media massa maupun lingkungan. ${ }^{47}$

Lebih lanjut Notoatmojo mengatakan bahwa, "Pengetahuan merupakan domain yang sangat penting untuk terbentuknya tindakan seseorang.Pengetahuan diperlukan sebagai dukungan dalam menumbuhkan rasa percaya diri maupun sikap dan perilaku setiap hari sehingga dapat dikatakan bahwa pengetahuan merupakan fakta yang mendukung tindakan seseorang". ${ }^{48}$

Untuk menjalani suatu kehidupan di bumi ini, manusia membutuhkan pengetahuan yang akan menuntun manusia dalam menghadapi segala permasalahan dan cobaan hidup. Tanpa pengetahuan, maka manusia tidak akan dapat menjalani hidupnya dengan baik. Oleh sebab itulah setiap manusia perlu mengenal siapa Allah dengan benar, sehingga melalui pengenalan akan Allah tersebut pengetahuan yang sejati itu akan menjadi bagiannya.

\section{Kehidupan}

"Takut akan TUHAN adalah sumber kehidupan sehingga orang terhindar dari jerat maut”. (Amsal. 14:27).

Dalam PL hidup biasanya menunjuk pada keadaan hidup di dunia sekarang ini, yang diakhiri dengan mati. Tetapi, hidup ini adalah

\footnotetext{
${ }^{46}$ W.R.F. Kamus Alkitab (Jakarta: BPK Gunung Mulia, 2007), 330.

${ }^{47}$ Point.htmlhttp://repository.usu.ac.id/bitstream/123456789/19202/4/Chapter\% 20II.pdf

${ }^{48} \mathrm{Ibid}$.
} 
pemberian Allah (Ul. 30:19). Dalam PB kata hidup sering menunjuk pada hidup kekal (Rm. 6:23), terutama dalam Injil Yohanes (mis.Yoh. 6:48).

"Sumber kehidupan" yang dimaksudkan kitab amsal di sini adalah ketika manusia mengenal TUHAN, maka manusia akan memiliki hidup karena TUHAN itu sendiri adalah sumber kehidupan manusia.Allah merupakan sumber dari kehidupan itu sendiri Rick Warren mengatakan bahwa, "Allah bukan sekadar titik awal dalam kehidupan anda; Dialah sumber kehidupan. Untuk menemukan tujuan hidup anda, anda harus melihat Firman Allah, bukan hikmat dunia.Anda harus membangun kehidupan anda di atas kebenaran-kebenaran kekal, bukan psikologi umum, motivasi sukses, atau kisah-kisah yang memberiinspirasi”. 50

Setiap manusia seharusnya menyadari bahwa TUHAN adalah yang menjadi pusat dari kehidupannya.

\section{Umur Panjang}

"Takut akan TUHAN memperpanjang umur, tetapi tahun-tahun orang fasik diperpendek". (Amsal. 10:27)

Kata "memperpanjang" di sini menggunakan kata "Yacaph", yaw-saf, a prim root to add or augment (often, To continue to do a thing) sebuah akar formal untuk menambah atau meningkatkan (sering, untuk terus melakukan apapun). Sedangkan kata "umur" digunakan kata "Yowm", yome; from an unused root mean.To be hot; a day (as the warm hours), whether lit. (from sunrise to sunset, or from one sunset to the next)._ dari akar kata yang tidak berarti. Untuk menjadi panas; hari (sebagai jam hangat), apakah menyala. (dari matahari terbit sampai terbenam, atau dari satu matahari terbenam ke berikutnya). ${ }^{51}$

Diterjemahkan ke dalam bahasa inggris "prolongs days" yang secara harfiahnya dapat diartikan "memperpanjang hari".

Dalam hal ini penulis kitab amsal ingin mengatakan bahwa siapa yang hidup menghormati TUHAN dalam setiap langkah kehidupnya setiap hari, maka "hari-hari dalam hidupnya akan terus diperpanjang oleh TUHAN sendiri dengan kata lain hidupnya akan lebih lama di bumi ini dibandingkan dengan orang-orang yang hidup tidak takut akan TUHAN.Ada jaminan umur panjang bagi siapa saja yang memilih takut akan TUHAN.Ketaatan manusia terhadap TUHANakan membawa kebahagiaan yang sejati dibandingkan dengan orang-orang yang tidak hormat terhadap TUHAN. Setiap orang di dunia ini telah ditentukan

\footnotetext{
${ }^{49}$ W.R.F. Kamus Alkitab (Jakarta: BPK Gunung Mulia, 2007), 139.

${ }^{50}$ Rick Warren, The Purpose Driven Life (Malang: Gandum Mas, 2005), 20.

${ }^{51}$ James Strong, The Strong's Exhaustive Concordance Of The Bible (America: Thomas Nelson Publishers, 1990). 49.
} 
batas hidupnya oleh TUHAN, namun tidak ada satu orang pun yang tahu kapan dan bagaimana seseorang tersebut akan meninggal, sebab semuanya ada dalam pengaturan dan pengetahuan TUHAN semata. Oleh sebab itu, hanya TUHANlah yang menentukkan kehidupan setiap orang.

Jadi, setiap manusia dituntut untuk hidup senantiasa menghormati TUHAN agar hari-hari dalam hidupnya terus ditambah-tambahkan olehNya atau dengan kata lain umurnya diperpanjang oleh TUHAN yang empunya kehidupan itu sendiri. Sebab yang memegang dan memberikan hidup kepada setiap orang adalah TUHAN. Dengan kekuasaan-Nya dan kemahatahuan-Nya segala sesuatu yang terjadi dan akan terjadi terhadap setiap manusia diketahui-Nya. Sekalipun hal ini tidak dapat dipungkiri bahwa kenyataan yang terlihat dalam kehidupan manusia setiap hari justru banyak orang-orang jahat/orang-orang yang hidupnya lebih lama daripada orang-orang yang baik ataupun bisa dikatakan orang-orang Kristen yang percaya TUHAN.

\section{IMPLEMENTASI KONSEP TAKUT AKAN TUHAN DALAM KEHIDUPAN KEKRISTENAN}

Untuk dapat menerapkan konsep ini dalam kehidupan kekristenan orang percaya setiap hari, maka kitab amsal memberikan pengajaran, perintah dan petunjuk yang praktis bagaimana cara menjalani hidup setiap hari yang benar-benar menunjukkan penghormatan kepada TUHAN melalui pengenalan yang benar oleh setiap orang tentang TUHAN dan melakukan segala perintah-perintahNya, sehingga melalui tingkahlaku, perbuatan, tutur kata setiap manusia mencerminkan sikap hormat atau "takut akan TUHAN".

Prinsip-prinsip "takut akan TUHAN" yang perlu diterapkan dalam kehidupan kekristenan berdasarkan kitab amsal antara lain:

\section{Mengenal TUHAN Dengan Sungguh-Sungguh}

"Jikalau engkau mencarinya seperti mencari perak, dan mengejarnya seperti mengejar harta terpendam, maka engkau akan memperolah pengertian tentang takut akan TUHAN dan mendapat pengenalan akan Allah" (Ams. 2:4-5). Untuk dapat mengenal Tuhan dengan benar setiap manusia harus dengan sungguh-sungguh mencari dan berusaha untuk mengenal Dia. Kitab amsal memberikan gambaran mengenai sikap setiap orang yang memiliki pengertian tentang takut akan TUHAN seperti seseorang yang mencari perak. Ini berarti bahwa 
usaha untuk mengenal TUHAN adalah sesuatu yang sangat penting dalam kehidupan kekristenan setiap hari.

Ketika seseorang mengenal TUHAN dengan benar, maka dengan secara sadar seseorang tersebut akan mendapat pengertian tentang siapa TUHAN itu sehingga, di sinilah seseorang akan mendapat kesadaran untuk menghormati TUHAN yang disembahnya.

Pada dasarnya Allah bukanlah Allah yang tidak dapat dikenal oleh manusia, Allah dapat dikenal melalui pembacaan Firman Tuhan, berdoa, pujian dan persekutuan-persekutuan dengan orang percaya lainnya.

\section{Menjadikan TUHAN Sebagai Sandaran}

Percayalah kepada TUHAN dengan segenap hatimu, dan janganlah bersandar kepada pengertianmu sendiri (Ams. 3:5). Setiap orang Kristen yang percaya diperingatkan dan diperintahkan untuk percaya sepenuhnya kepada Tuhan, bersandar kepada-Nya dan tidak mengandalkan atau bersandar pada pengertiannya sendiri. Setiap orang yang mau berjalan dengan kekuatannya sendiri adalah orang yang tidak mengenal siapa Tuhannya, bahkan merupakan orang yang tidak menghormati dan menghargai Tuhan dalam hidupnya. "Perintah ini juga merupakan peringatan terhadap bersandar pada perasaan kita. Kesalahan ini banyak terjadi di antara orang Kristen. Bersandar pada Tuhan berarti mengenal Dia melalui firman-Nya, doa, dan melalui nasihat oranglain". ${ }^{52}$ Orang-orang Kristen yang sungguh-sungguh bersandar kepada Tuhan akan sehat dan bijaksana (Ams. 3:7). Amsal berkata orang yang bijak akan mewarisi kehormatan (Ams. 3:35). "kepercayaandiperintahkan; kepercayaan yang juga meliputi kepercayaan kepada Allah (ay. 5), mengakui Dia dalam segala bidang kehidupan (ay. 6), dan takut kepada Dia (ay. 7)".53 Ketika setiap orang menjadikan Tuhan sebagai sandaran dalam hidupnya itu berarti bahwa orang tersebut tidak akan menjadi gentar dan takut terhadap kekejutan yang tiba-tiba karena Dia sendirilah yang akan menghindarkan kaki manusia dari pada jerat (Ams. 3:26).

Percaya kepada Tuhan dengan segenap hati adalah lawannya meragukan Allah dan firman-Nya. Pengertian kita sendiri terbatas, dan mudah salah, dalam semua rencana, keputusan, dan tindakan kita, hendaknya kita mengakui Allah sebagai Tuhan dan kehendakNya sebagai keinginan tertinggi kita. Setiap hari kita harus hidup

\footnotetext{
${ }^{52}$ Robert Alden, Perilaku Yang Bijaksana: Tafsiran Amsal Salomo (Lembaga Reformed Injili Indonesia, 1991), 16.

${ }^{53}$ Tafsiran Alkitab Masa Kini 2 (Jakarta: BPK Gunung Mulia, 1976), 30.
} 
dalam hubungan yang erat dan percaya Allah, senantiasa mengharapkan pengarahan dari Dia. ${ }^{54}$

Dalam Amsal pasal 16:3 mengatakan, bahwa orang percaya seharusnya melakukan segala sesuatu dengan mengandalkan Tuhan karena dengan demikian seluruh rencana manusia akan terlaksana dengan baik. Paul G. Caram mengatakan, "orang yang tidak menyadari ketidakberdayaannya akan bersandar kepada Allah sedangkan orang yang percaya kepada kemampuannya sendiri dan bersandar kepada kemampuannya sendiri tidak mencari Allah".55 Pernyataan ini menyatakan kepada orang-orang percaya bahwa setiap orang yang bersandar kepada Tuhan adalah orang-orang yang sungguh-sungguh mengenal dan menyatakan kemahakuasaan Tuhan dalam hidupnya.

\section{Berjalan Dalam Kejujuran}

Siapa berjalan dengan jujur, takut akan TUHAN, tetapi orang yang sesat jalannya, menghina Dia (Ams. 14:2; Bdg Yoh. 14:15). "Berjalan dengan jujur merupakan sebuah bukti ketaatan, tetapi mengikuti jalan yang sesat adalah sebuah bukti ketidaktaatan kepada Tuhan". ${ }^{56}$ Setiap orang tidak luput dari ujian kejujuran bahkan orang percaya pun tanpa terkecuali. Sikap jujur merupakan wujud dari ketaatan manusia terhadap Tuhannya, ketika manusia tidak hidup dalam kejujuran, maka secara nyata manusia tersebut menghina Dia sebagai Tuhan. "kejujuran dan kejahatan pada dasarnya bersumber pada sikap orang terhadap Allah". ${ }^{57}$ Jadi, dengan kata lain bahwa kejujuran atau pun kejahatan yang setiap orang lakukan merupakan pemberontakannya terhadap Tuhan. kejujuran mengajarkan setiap orang akan keberadaan Tuhan sebagai pribadi yang Mahatahu. Tuhan menyediakan pertolongan bagi setiap orang yang jujur dan menjadi perisai baginya (Ams. 2:7). Jadi, ketika manusia menempuh hidup dalam kejujuran berarti orang tersebut telah menjadikan Tuhan sebagai pelindung dan perisai dalam kehidupannya dan sungguh-sungguh menyadari akan keberadaan Tuhan sebagai yang mahakuasa dalam kehidupannya. Orang-orang jujur akan mendiami tanah (Ams. 2:21). Tuhan bergaul erat dengan orang jujur (Ams. 3:32).

Hidup jujur juga merupakan salah satu sikap manusia yang mengakui kehadiran Tuhan setiap waktu dalam kehidupannya. Dalam Amsal pasal 11:1, juga di sana digambarkan bahwa salah satu perbuatan

\footnotetext{
${ }^{54}$ Alkitab Penuntun Hidup Berkelimpahan (Malang: Gandum Mas, 2000), 967.

${ }^{55}$ Paul G. Caram, Kekristenan Sejati (Jakarta: Voice Of Hope, 2007), 101.

${ }^{56}$ Robert Alden, Perilaku Yang Bijaksana: Tafsiran Amsal Salomo (Lembaga Reformed Injili Indonesia, 1991), 79.

${ }^{57}$ Tafsiran Alkitab Masa kini 2 (Jakarta BPK Gunung Mulia, 1976), 33.
} 
yang tidak jujur adalah pemakaian neraca yang tidak benar untuk menipu oranglain juga merupakan kekejian bagi Tuhan. Tuhan memerintahkan manusia agar bertindak jujur kepada semua orang, baik dalam hal keuangan maupun dalam keadaan lain yang memungkinkan penipuan. "hanya ketika kita mengukur motivasi pribadi dengan standar kebenaran Alkitab, barulah kita melihat kesalahan dari jalan kita. Allah tidak dapat ditipu dengan ketidakjujuran atau alasan kita yang bagus.Ia menghakimi motivasi (Ams. 16:2)". ${ }^{58}$

\section{Menjauhi Kejahatan}

"Dengan kasih dan kesetiaan, kesalahan diampuni, karena takut akan TUHAN orang menjauhi kejahatan". (Ams. 16:6 bdg 4:27). Dengan menjauhkan diri dari kejahatan, berarti membuktikan bahwa orang tersebut memiliki penghormatan terhadap Tuhan lewat tingkahlakunya. "Tuhan membenci dosa, bukan membenci orang berdosa."Menurut (Ams. 15:9), Tuhan membenci jalan orang jahat, bukan orang jahat itu sendiri". ${ }^{59} \quad$ Bangsa Israel dikelilingi oleh bangsa-bangsa yang kesukaannya hanya melakukan kejahatan dan oleh karena itulah Salomo memberikan nasihat dalam amsal pasal 1:15-16, agar tidak menurut tingkahlaku mereka (bdg Ams. 5:14-18).

Menjauhi kejahatan merupakan keharusan bagi setiap orang Kristen yang percaya bukan merupakan paksaan (Ams. 8:13). Kejahatan merupakan sikap pemberontakkan manusia terhadap Tuhan, kejahatan merupakan sikap yang tidak menghormati Tuhan. Salah satu bukti bahwa manusia menghormati Tuhan dalam kehidupannya adalah dengan menjauhkan diri dari kejahatan-kejahatan dalam bentuk apa pun yang tidak memuliakan Tuhan. Kekristenan harus menjadi berkat bagi orangorang yang ada disekitarnya dengan menunjukkan tingkahlaku dan perbuatannya dalam hidup bermasyarakat setiap hari.

\section{Memiliki Sikap Hati yang Benar}

"Enam perkara ini yang dibenci TUHAN, bahkan, tujuh perkara yang menjadi kekejian bagi hati-Nya: mata sombong, lidah dusta, tangan yang menumpahkan darah orang yang tidak bersalah, hati yang membuat rencana-rencana yang jahat, kaki yang segera lari menuju kejahatan, seorang saksi dusta yang menyembur-nyemburkan kebohongan dan yang menimbulkan pertengkaran saudara" (Ams. 6:1619). Hati bagi orang Yahudi merupakan pusat dari seluruh keberadaan hidup manusia. Amsal pasal 6:18, memperingatkan manusia untuk selalu

\footnotetext{
${ }^{58}$ Ibid. 35.

${ }^{59}$ Tafsiran Alkitab Masa kini 2 (Jakarta BPK Gunung Mulia, 1976), 88.
} 
menjaga hati dari segala rencana-rencana yang jahat karena ini merupakan satu dari enam bahkan tujuh perkara yang dibenci oleh Tuhan dalam hidup manusia (ay.16). Dari hati juga terpancar kehidupan (Ams.4:23). Hati yang benar akan memancarkan kehidupan yang benar dan memuliakan Tuhan. "Secara alkitabiah, hati dapat dilihat sebagai berisi seluruh pikiran, perasaan, dan kehendak seseorang. Hati adalah pusat intelek (bdg.U1.8:5; 1Sam. 1:12-13; Mzm. 19:15). Hati adalah pusat perasaan (bdg.Kel.4:14; Ul.6:5; Yos. 5:1; Mzm. 27:14). Hati adalah pusat kehendak manusia (bdg.Kel.4:21; Yos.24:23; 2Taw.6:7; 1Taw. 22:19)".60

Dengan memiliki sikap hati yang baik juga setiap orang akan menerima firman-Nya dengan baik dan menyimpannya, sehingga manusia dapat hidup bijaksana dan benar dalam hubungannya dengan Tuhan dan akan memperoleh pengertian tentang takut akan TUHAN (Ams. 2:5). Tuhan dapat mengetahui apa yang ada dalam hati manusia, oleh sebab itu milikilah hati yang benar karena Tuhan tahu semua isi hati manusia tanpa terkecuali (Ams. 15:11).Setiap orang perlu menjaga hati. Dari hati manusia akan timbul berbagai macam hal yang tidak memuliakan Tuhan.Bukan korban, bukan harta yang banyak, bukan kecantikan dan kegagahan, bukan prestasi yang Tuhan cari dari setiap orang percaya, akantetapi Tuhan mencari dan melihat hati manusia.Sebagaimana yang diungkapkan Paul G. Caram bahwa, "Allah tidak menghendaki korban dari kita jika hati kita tidak benar terhadapNya." $" 1$

\section{PENUTUP}

\section{Kesimpulan}

Kekristenan seharusnya hidup berdasarkan takut akan TUHAN dengan menyadari akan kemahakuasaan-Nya, kekudusan-Nya, kemahahadiran-Nya dan kemahatahuanNya dalam setiap aspek kehidupan manusia lewat tindakan dan perilaku manusia. Banyak hal dalam dunia ini yang akan membuat manusia merasa takut dan gentar, baik itu ketakutan terhadap sesamanya manusia maupun ketakutan terhadap hal-hal yang lainnya. Takutakan TUHAN merupakan suatu perasaan takut yang positif bukan negatif. Takutakan TUHAN bukan seperti perasaan takut yang dialami oleh manusia terhadap hal-hal yang biasa, tetapi takutakan TUHAN merupakan penghormatan manusia terhadap TUHAN. Pula tidak jarang setiap orang menganggap bahwa

\footnotetext{
${ }^{60}$ Alkitab Penunutun Hidup Berkelimpahan (Malang: Gandum Mas, 2000), 972.

${ }^{61}$ Paul G. Caram, Kekristenan Sejati (Jakarta: Voice Of Hope, 2007), 75.
} 
TUHAN itu adalah satu pribadi yang menakutkan karena banyaknya pelanggaran yang terdapat atau diperbuat oleh manusia tersebut. Takutakan TUHAN harus didasari oleh karena "rasa hormat manusia terhadap TUHAN" bukan karena takut akan "hukuman TUHAN". Dalam kitab Amsal ada beberapa manfaat yang akan diperoleh oleh setiap orang yang hidup dalam takut akan TUHAN. Pertama, hikmat merupakan keterampilan yang dimiliki oleh seseorang dalam menjalani kehidupannya. Kedua, pengetahuan tentang siapa ALLAH. Ketiga, kehidupan. Dalam hal ini yang dimaksudkan adalah kehidupan kekal. Keempat,umur panjang. Takut akan TUHAN banyak kali dilupakan oleh manusia, karena manusia kadang tidak menyadari bahwa ALLAH yang disembahnya adalah ALLAH yang mahahadir dan mahatahu. Kitab Amsal merupakan kitab puisi di dalam Perjanjian Lama yang banyak berbicara tentang kata "Takutakan TUHAN". Oleh karena itu, kitab inilah yang menjadi pusat penelitian dari penulis untuk membahas konsep tentang takut akan TUHAN. Penghormatan setiap orang kepada TUHAN harus diwujudnyatakan setiap hari dalam seluruh aspek kehidupan manusia. Manusia "Takut akan TUHAN" adalah suatu sikap penghormatannya terhadap TUHAN yang disembah.

\section{Saran}

Berdasarkan kesimpulan di atas, maka di sini penulis mencoba memberikan saran-saran sebagai acuan bagi kehidupan kekristenan dalam menjalani setiap aspek kehidupan setiap hari.Adapun saran-saran tersebutsebagaiberikut:Pertama, kehidupan kekristenan seharusnya mengenal dengan benar siapa TUHAN yang dipercayainya, mencari DIA dengan sungguh-sungguh melalui pembacaan Firman Tuhan dan membangun hubungan yang intim dengan TUHAN. Kedua,kehidupan kekristenan seharusnya menyadari dengan benar keberadaan ALLAH dalam kehidupan setiap manusia sebagai ALLAH yang mahakuasa, mahatahu, mahahadir dan mahakudus yang mampu melakukan apa pun juga tanpa terkecuali terhadap kehidupan setiap manusia. Ketiga, kekristenan tidak seharusnya memandang ALLAH hanya sebagai ALLAH yang transenden saja, tetapi kekristenan pun harus menyadari bahwa ALLAH juga adalah ALLAH yang imanen yang dekat dengan manusia. Keempat, kekristenan tidak boleh mempunyai paradigm bahwa setiap orang harus takut terhadap TUHAN karena takut akan hukuman melainkan takutkarena "hormat" kepada DIA. Kelima, kehidupan orang Kristen seharusnya menjadi teladan bagi setiap orang yang ada di sekitarnya dalam hal penghormatannya terhadap Allah, agar setiap orang dapat melihat bahwa kekristenan benar-benar memiliki Allah yang hidup di dalam kehidupan mereka secara nyata. 


\section{KEPUSTAKAAN}

Alkitab. Jakarta: Lembaga Alkitab Indonesia. 2000.

Alkitab Penuntun Hidup Berkelimpahan. Malang: Gandum Mas. 2000.

Alkitab Edisi Studi. Jakarta: Lembaga Alkitab Indonesia. 2010.

Ensiklopedi Alkitab Masa Kini Jilid I. Jakarta: Yayasan Komunikasi Bina Kasih/OMF. 2002.

Ensiklopedi Alkitab Masa Kini Jilid II. Jakarta: Yayasan Komunikasi Bina Kasih/OMF. 1995.

Kamus Umum Bahasa Indonesia. Jakarta: Pustaka Sinar Harapan. 1994.

Oxford Dictionary. New York: Maurice Waite. 1994.

Tim Penyusun Kamus Pusat Pembinaan dan Pengembangan Bahasa. Jakarta: Balai Pustaka. 1995.

Kamus Besar Bahasa Indonesia. Jakarta: Balai Pustaka. 1995.

W.R.F. Kamus Alkitab. Jakarta: BPK Gunung Mulia. 2007.

Tafsiran Alkitab Masa Kini 2. Jakarta: BPK Gunung Mulia. 1976.

The New Strong's. America: Thomas Nelson Publishers. 1990.

\section{Buku-Buku}

Alden, Robert. Perilaku yang Bijaksana. Lembaga Reformed Injili Indonesia. 1991.

Ammerman, L. M. dan Maritim. Melihat ke Dalam Perjanjian Lama. Bandung: . Kalam. Hidup. 1979.

Baker, D. L. Pengantar Bahasa Ibrani. Jakarta: BPK Gunung Mulia. 2008.

Balchin, John Dkk. Intisari Alkitab Perjanjian Lama. Jakarta: Persekutuan Pembaca. Alkitab. 2005.

Berkhof, Louis. Teologi Sistematika I. Lembaga Reformed Injili Indonesia. 1993.

Bullock, C. Hassel. Kitab-Kitab Puisi Dalam Perjanjian Lama. Malang: Gandum Mas. 2003. An Introduction to the Old Testament Poetic Books. America: The Moody Bible Institute. 1979.

Caram, Paul G. Kekristenan Sejati. Jakarta: Voice Of Hope. 2007.

Dyrness, William. Tema-Tema Dalam Teologi Perjanjian Lama. Malang: Gandum Mas. 1990.

Davidson, Benjamin. "The Analytical Hebrew And Chaldee Lexicon".

Evans, Tony dan Moody. Teologi Allah. Malang: Gandum Mas. 1999.

Frame, John M. Doktrin Pengetahuan Tentang Allah. Malang: Departemen Literatur Saat.

Falwel, Jerry. Wisdom For Living. America: SP Publications Inc. 1984. 
Green, Dennis. Pengenalan Perjanjian Lama. Malang: Gandum Mas. 1984.

Harlow, R. E. Proverbs the King's Wisdom. Canada: Everyday Publications Inc. 1984.

Hill, Andrew E. dan John Walton. Survei Perjanjian Lama. Malang: Gandum Mas. 1996.

Lasor, W. S . Dkk. Pengantar Perjanjian Lama 2. Jakarta: BPK Gunung Mulia. 1994.

Lea, Larry. Hikmat. Jakarta: Yayasan Pekabaran Injil “IMANUEL”. 1998.

Longman, Tremper III. Hikmat dan Hidup Sukses. Jakarta: Persekutuan Pembaca Alkitab. 2007.

Lumintang, Stevri I. Teologi Abu-Abu. Malang: Gandum Mas. 2004.

O'collins, Gerald Dkk. Kamus Teologi. Kanisius: Anggota IKAPI. 1996.

Rimba, Retnawaty. Intisari Alkitab Perjanjian Lama. Jakarta: Persekutuan Pembaca. Alkitab. 2005.

Ryle, J.C. Aspects of Holiness. Surabaya: Momentum Christian Literature. 2003.

Sekolah Tinggi Theologia Injili Indonesia. Yogyakarta: STII. 1996.

Towns, Elmer L. Nama-Nama Allah. Yogyakarta: Yayasan ANDI. 1981.

Tozer, A. W. Mengenal Yang Mahakudus. Bandung: Kalam Hidup. 1993.

Warren, Rick. The Purpose Driven Life. Malang: Gandum Mas. 2005.

Welch, Edward T. Ketika Manusia Dianggap Besar dan Allah Dianggap Kecil. Surabaya: . Momentum Christian Literature. 2003.

Wendel, Francois. Calvin: Asal-Usul dan Perkembangan Religiusnya. Surabaya: Momentum Christian Literature. 2010.

Wong, Amy NG. God From A To Z. Yogyakarta: ANDI. 2005.

Internet

John Hick. Religious Pluralism dan Salvation (Faith \& Philosophy Journal Vol.5 1988), 37l; diakses tanggal 23 April 2011. Tersedia di http://www.google.co.id/search?client=firefox-

a\&erls=org.mozilla\%3Aen

US\%3Aofficial\&channel=s\&hl=id\&source=hp\&\&q=pendapat + para

+ ahli + theologia + ttg + adanya + Allah $\&$ meta $=\& b t n G=$ Penelusuran + Google.

Point; diakses Tanggal 23 April 2011. Tersedia di

http://repository.usu.ac.id/bitstream. 